\title{
A MILLION FRUIT TREES FOR THE COUNTRYSIDE
}

\author{
VÍT HRDOUŠEK ${ }^{1}$, BORIS KRŠKA ${ }^{2}$, PETR KULÍŠEK ${ }^{3}$, RADIM LOKOČ $^{4}$ \\ ${ }^{1}$ MAS Strážnicko, programme coordinator, nám. Svobody 501, 69662 Strážnice, email: \\ vit.hrdousek@seznam.cz \\ ${ }^{2} Z F$ Mendelu Brno, profesor, Valtická 337, 69144 Lednice; email: \\ boris.krska@mendelu.cz \\ ${ }^{3} K S$ MAS JMK, project manager, Kostelecké horky 25, 517 41, email: \\ petr.kulisek@kosteleckehorky.cz. \\ ${ }^{4} \mathrm{ZO}$ ČSOP, fruiterer, Leverki̊v ostrov, Průkopnická 1874720 Vřesina, email: \\ radim.lokoc@centrum.cz
}

Received: $31^{\text {th }}$ October 2016, Accepted: $31^{\text {th }}$ November 2016

\section{AbSTraCT}

Innovative programme of so-called functional planting of fruit trees in Bohemia, Moravia and Silesia in order to increase the resilience of the territory to climate change.

Keywords: functional planting, fruit trees, suitable varieties, climate change

\section{INTRODUCTION AND OBJECTIVES}

The cooperative programme of Local Action Groups (LAGs) and professional institutions, with the support of regional authorities, was established in early 2016 to restore planting of fruit trees in the countryside. It aims to preserve and strengthen the traditional fruit-growing in Bohemia, Moravia, and Silesia, with its production and non-production functions such as enhancing biodiversity, water and soil retention, support of short supply chains, and increasing the overall resilience of the territory to climate change.

\section{METHODS AND FOCUS}

The programme brings together a wide range of experts and institutions from the Czech Republic in order to formulate options and the realisation of so-called functional planting in the cultural landscape of Bohemia, Moravia, and Silesia using new standards for planting fruit trees in landscape (Boček et. al, 2016). The programme focuses on the utilisation of the fruit-growing tradition for the new planting of solitary trees, (tree) alleys and orchards within ÚSES features (ÚSES - territorial system of environmental stability), greenery in accordance to ÚPD (urban planning documentation), KPÚ and landscape features according to DZES (GAEC - Good Agricultural and Environmental Condition ) in the cultural landscape. The starting point is the experience with the planting of fruit trees over the past 20 years and also the legislation, especially the professional standards of Nature Conservation Agency of the Czech Republic, particularly the new NCA CR Standard SPPK-C02-03: Functional planting of fruit trees in the agricultural landscape. The publication lists useful websites with detailed 
information on particular issues, such as drought, erosion, soil, fruit varieties, tree growers, legislation, etc. In a campaign conducted over the Internet and with printed materials, the programme addresses not only local governments and government agencies but also non-governmental organisations and the general public living in the country in order to draw attention to this issue.

\section{RESULTS}

The first educational results of this cooperative programme, apart from pilot planting in South Moravia, are contained in a publication called Handbook for planting fruit trees in Bohemia, Moravia, and Silesia and the website www.milionstromu.cz. The publication and the website present a wide range of possibilities and the importance of so-called extensive functional planting of fruit trees in the countryside. Functional planting must meet, apart from production functions, also non-productional functions, especially landscaping, erosion control, and environmental, social and cultural functions. The programme defines and demonstrates ways to preserve, grow and utilise local, regional, traditional and other resistant varieties and species of fruit trees.

Fig. 1: Functional planting of suitable varieties of fruit trees into local biokoridor „Barborka“" near Kroměříž town in central Moravia

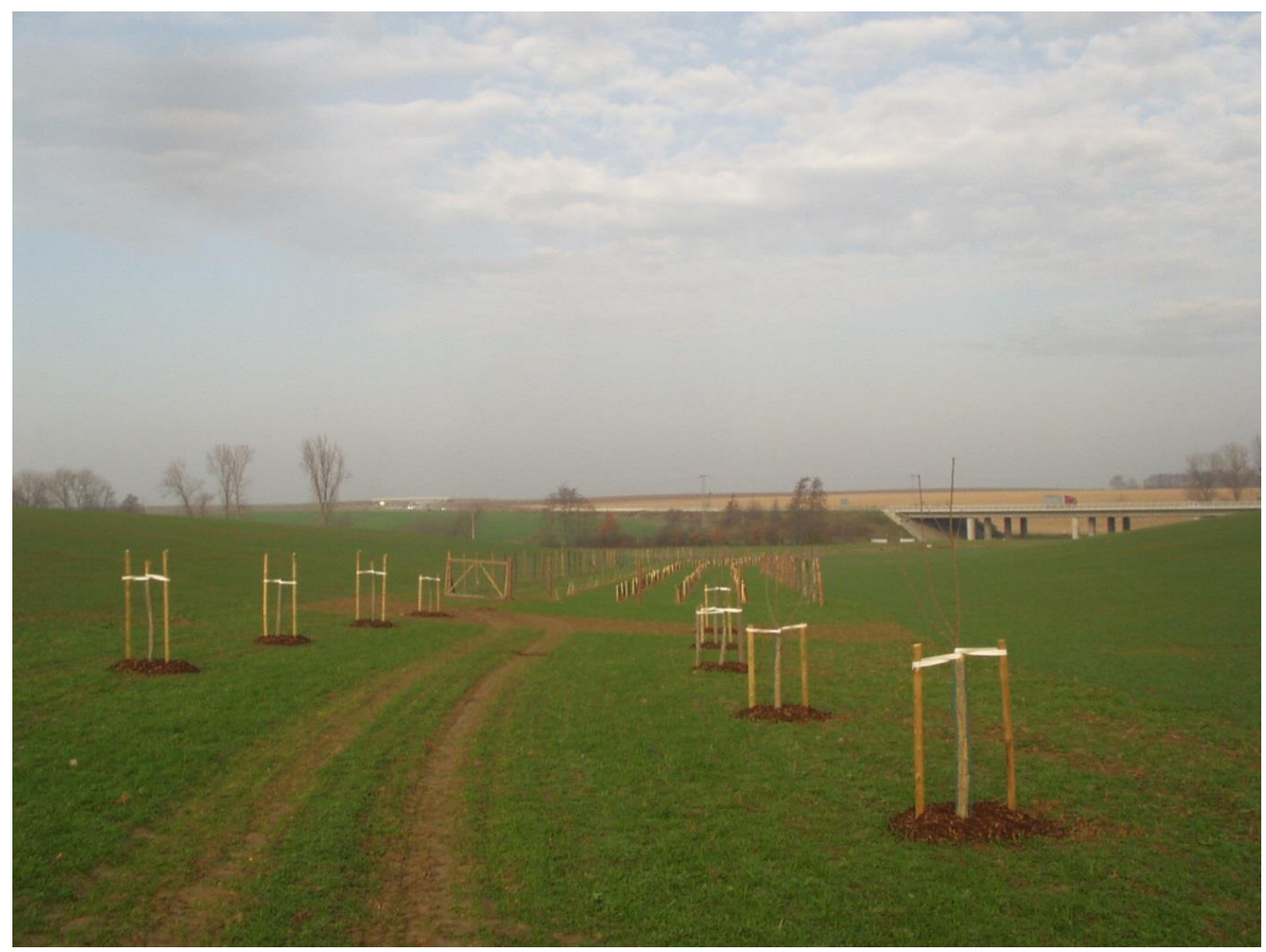

The publication summarises the most appropriate means of enforcement and implementation of (landscape) planting for the current conditions, introduces options, restrictions and limits of planting from the legislative and professional perspective. The 
practical part of the publication lists different kinds of fruit plantings in the countryside and a selection of suitable varieties and species of fruit trees in various climatic conditions. The publication presents principles of planting and care of fruit trees, including pruning in various stages of the life of a tree. It offers clear options and procedures for the establishment and maintenance of functional planting. Apart from descriptions, there are also price lists of plantings, links to the relevant subsidy programmes, photographs and drawings.

The publication and the website offer inspiration for those interested in fruit tree planting and fruit-growing, including a number of examples of good practices carried out by associations, communities, and municipalities, and also successful projects to preserve old and regional varieties and projects showing the restoration of traditional landscape features. Multiplication of the gene pool, planting and subsequent utilisation of fruit may be realised with financial support by the end of 2023 thanks to grants prepared by the Ministry of Environment and the Ministry of Agriculture with the EU subsidies.

Fig. 2: Local variety of red pear in genofond landcape orchard in Tvarožná Lhota village in south Moravia

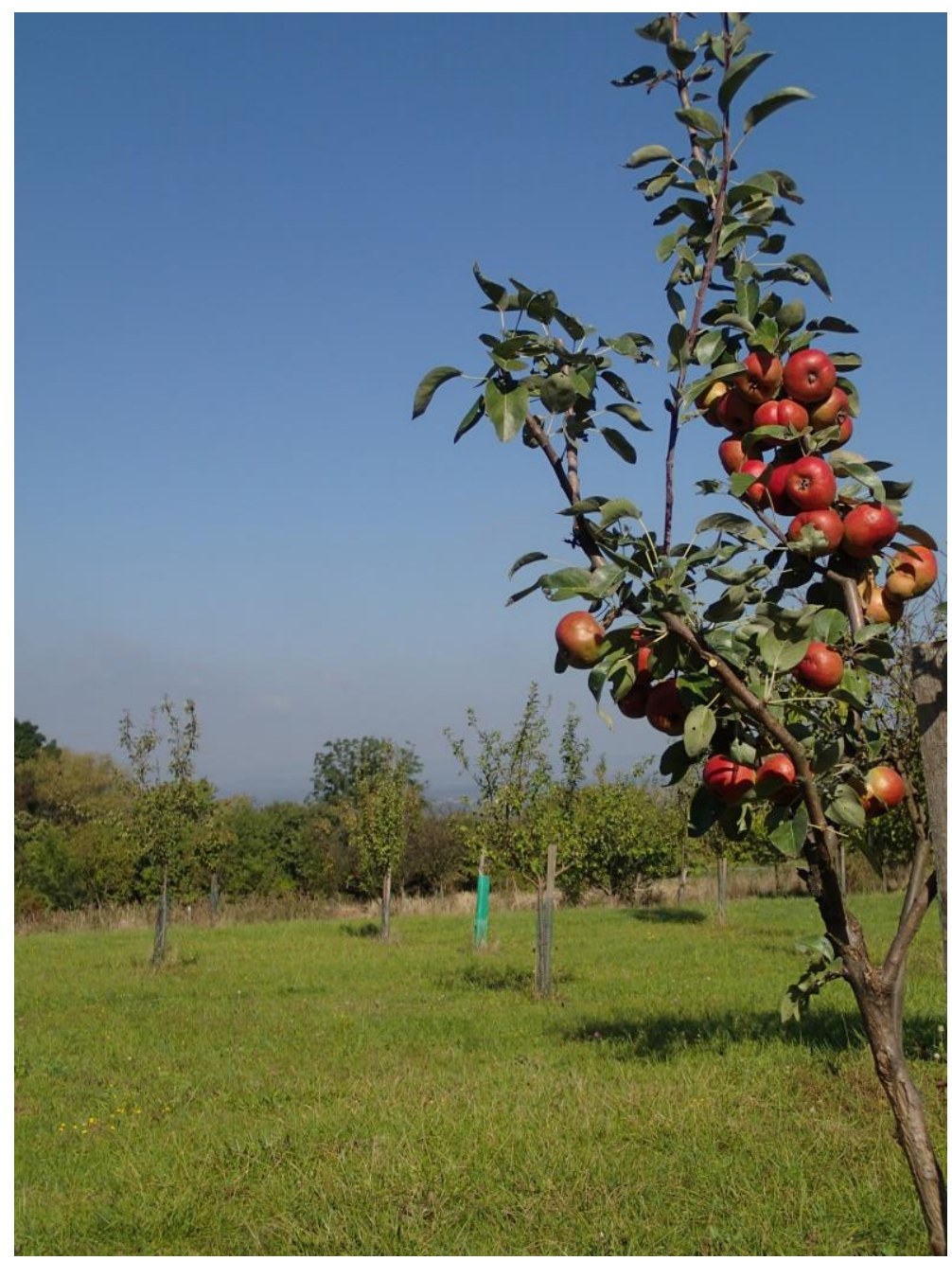




\section{CONCLUSION}

The pilot LAG CR programme called "A Million fruit trees for the countryside" was launched through community planting, the publication of the handbook, and the creation of the website in 2016. These first outcomes promote blanket application of functional planting of fruit trees in the countryside. It may bring positive effects of resilience to climate change and development of short supply chains.

\section{REFERENCES}

Boček a kol., (2016). SPPK C02 003 Funkční výsadby ovocných dřevin v zemědělské krajině, AOPK ČR. 